DOI: https://doi.org/10.47405/mjssh.v6i9.992

\begin{tabular}{|c|c|}
\hline & Malaysian Journal of Social Sciences and Humanities (MJSSH) \\
\hline Malaysian Journal of & Volume 6, Issue 9, September 2021 \\
\hline (MJ-SSH) & e-ISSN : 2504-8562 \\
\hline & $\begin{array}{l}\text { Journal home page: } \\
\text { www.msocialsciences.com }\end{array}$ \\
\hline
\end{tabular}

\title{
The Influence of Employee Demotivation and Employee Motivation on Employee Performance: A Case Study of Farven
}

\author{
Elma Soraya1, Rudy Bekti1 \\ ${ }^{1}$ School of Business and Management, Institut Teknologi Bandung, Indonesia \\ Correspondence: Elma Soraya (elma_soraya@sbm-itb.ac.id)
}

\begin{abstract}
Workers as an essential to give their efforts in every action to achieve goals in the organization. Workers need triggers to do things well and produce good performance, one of the driving factors is good motivation. Good motivation will result in high performance, low turnover, loyalty, alignment, which contributes significantly to the growth and development of the company. Conversely, if the driving factor is bad motivation or commonly called demotivation, it will result in low performance, high turnover, low loyalty, absence of alignment, nor does it contribute significantly to the growth and development of the company. Moreover, currently the country of Indonesia is a developing country that has great potential to compete in the field of development, one of the developments for human resources that have good quality, which will affect the results of work and company. Farven as a startup that has workers want to also contribute in developing good resources by maintaining good quality workers, but Farven has some challenges one of which is the problem of worker demotivation that has been felt by all Farven workers. In this study, researchers aimed to know the dimensions of worker demotivation and worker motivation that affect worker performance and wanted to know the indicators of the dimensions that most influence the demotivation of workers and also the motivation of workers. Researchers used a semi-structure interview in the interview process to three Farven workers. The order of questions may also vary depending on the conversation flow. On the other hand, additional questions, and objectives with the nature of certain events in a particular organization. Informant will be selected through nonprobability sampling i.e. purposive sampling or specifically using judgement sampling. The interview will primarily explore the dimensions of employee motivation and employee motivation according to the participant's experience as a Farven employee. This study used thematic coding to analyze qualitative data.
\end{abstract}

Keywords: employee demotivation, employee motivation, demotivation dimension, motivation dimension, employee performance

\section{Introduction}

Indonesia is a developing country with great potential to compete with other countries in various ways, one of which is development. Of course, as a developing country, development is done rapidly to get good quality. Human resources management is needed to get the excellent and maximum quality, which will impact work results and the company. Human resources can conclude that they are the key to compete in the free-market era (Fulmer \& Ployhart, 2014). 
In achieving the goals of an organization, employees become the most vital force in giving effort and relentless effort in every action. Therefore, employees are considered as the foundation and are essential in the organization. In human resource strategy, motivation cannot separate, which is a necessary part of employees doing a good performance in an organization (Kamal and Ii, 2012) in getting good human resources, there needs to be a trigger to do something well and produce a good performance, one of the factors of the catalyst is good motivation.

Demotivation, as defined by Falout, Elwood and Hood (2009a) is a decrease or drop in level of motivation. According to Jarour (2014) The causes of demotivation can be divided into three categories. Financial resources are the first category. Workplace initiatives are the second type. The external environment, which is related to the organization indirectly, is the final category. Different demotivating factors must exist for everyone, resulting in lower work performance (Jarour, 2014).

\section{Business Issued Faced}

Farven, as a brand fashion start-up, is also a small and new company in the industry facing crucial problems that affect the employee's performance. The problem that was first exposed about the decrease in the effectiveness of the company, it can be seen from OKR company not achieved, the KPI progress only reaches $20 \%$, the job desk that is not implemented, and the monthly target is not achieved. From the description, the main problem is because there is a demotivation of employees that affects employee's performance.

\section{Literature Review}

\section{Employee Demotivation}

Demotivation can have affect a employee's attitudes and behaviour (Falout, Elwood and Hood, 2009b). Demotivation can affect employee performance and commitment, it must be sought for factors that greatly influence it in order to be overcome so as not to threaten the sustainability of the company (Sohail et al., 2014)

Demotivation has a variety of factors, which vary from person to person. Secondary activities, such as a person's normal day work, can demotivate them at times. Management in any firm should conduct frequent study on its employees to discover if any changes have occurred that could contribute to demotivation (Jarour, 2014).

Demotivation is defined as a lack of motivation combined with inaction (Falout, Elwood and Hood, 2009b). Amotivated people have a lack of competence or control over their external settings, as well as a sense of powerlessness brought on by a lack of contingency between their actions and their consequences (Falout, Elwood \& Hood, 2009b).

\section{Employee Motivation}

Motivation is the process of inducing effective activities targeted at achieving organizational goals and meeting the requirements of employees by amplifying the impact of both internal and external stimuli on their activities. The process of employee motivation in organizations has a different and unpredictable nature because of the influence of various dimensions, the influence of different motives, and will produce different activity results. As a result, motivation is a complicated and ambiguous process (Halushchak \& Halushchak, 2016).

Motivation is one of the most important variables in increasing a company's efficiency. Motivation itself is influenced by many factors, including the social, cultural, and individual environment of each person. This is what causes the absence of a standard that can be used to measure and compare the level of motivation between one company and another (Liedianto and Andi, no date) 


\section{Employee Performance}

Employee performance refers to an employee's productivity and production as a result of their growth. Employee performance has a direct impact on the efficiency of an organization (Asstprof, 2013).

According to Mayasari (2020), Demotivation is one of several elements that might influence an employee's level of performance. Demotivation has a negative impact on employees and even the company's long-term viability because it increases staff turnover. However, Inuwa (2016) motivation elements, on the other hand, promote workplace engagement by making work more meaningful and engaging, as well as by making employees more effective and so enhancing their job performance. He also stated that motivational variables may be able to mitigate the detrimental impacts of demotivation, resulting in improved employee performance.

\section{Methodology}

\section{Research Design}

Research design is the path that researchers must pass to conduct research. It shows a way for researchers to formulate their problems and objectives and present their results from the data obtained during the study period.

Figure 1: Research Design

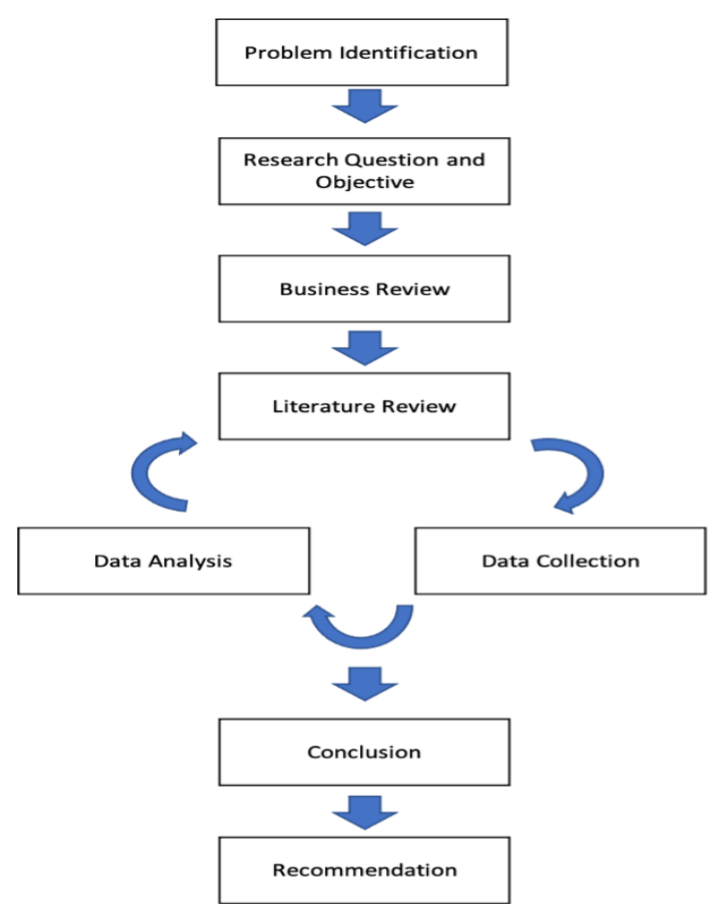

\section{Problem Identification}

Researcher try to find problems that are being faced by the company, after that identify the problems to be brought up to the research topic. The first problem researcher noticed was the existence of decrease Organizational Effectiveness and after that we broke down the problem, it turned out that the root cause was in employee demotivation.

\section{Research Question and Objectives}

After carrying out problem identification, of course, there are objects that the researcher wants to know and explore, these are included in the research question and research objectives. 


\section{Business Review}

It is also important to review the business because the continuity of business problems and research questions is important, a business overview makes it easier for researcher to see the core problems in the business.

\section{Literature Review}

Researcher need literature review to support this research and strengthen the opinion with data from previous research, books, and journals. Researchers need literature review about employee performance, employee demotivation, and employee motivation.

\section{Data Collection}

The researcher will prepare the data collection method using semi-structured interviews and will gather the data from Farven's three employees: CMO, COO, and Sales Manager. Interviews will be conducted in person with the aim of exploring what dimensions influence employee demotivation and employee motivation on employee performance, and Indicator dimensions of employee demotivation and employee motivation has influence employee performance.

\section{Interview Design}

In the interview design, the question list is arranged to explore what dimensions an effect on employee demotivation and employee motivation on employee performance and Indicator dimensions of Employee Demotivation and Employee Motivation have has influence Employee Performance.

Table 1: Interview Question and Measurement Overview Table

\begin{tabular}{|c|c|c|}
\hline Topic & Concept & $\begin{array}{l}\text { Measurement } \\
\text { Instrument }\end{array}$ \\
\hline Introducing & $\begin{array}{l}\text { Employee introduce his/her self and how long } \\
\text { in Farven and job desk description }\end{array}$ & Question: Q01 \\
\hline Company Overview & $\begin{array}{l}\text { The overview mainly discusses about the } \\
\text { company profile; history, vision } \\
\text { and mission, and values. }\end{array}$ & Question: Q02 \\
\hline Social relations at work & $\begin{array}{l}\text { In this part, the interview discusses the } \\
\text { relationship between workers and other } \\
\text { workers. What makes them motivated as well } \\
\text { as demotivating in social relationships }\end{array}$ & Question: Q03 \\
\hline Job Characteristics & $\begin{array}{l}\text { Discuss what kinds of work they like and } \\
\text { don't like. Consider what made them choose } \\
\text { the job. What makes them motivated and also } \\
\text { demotivating in the characteristics of the job } \\
\text { they choose }\end{array}$ & Question: Q04 \\
\hline Job Guarantee & $\begin{array}{l}\text { Types of Job Guarantee given to workers, are } \\
\text { there rewards and punishments given or } \\
\text { bonuses or other things. What makes them } \\
\text { motivated as well as demotivating in Job } \\
\text { Assurance }\end{array}$ & Question: Q05 \\
\hline $\begin{array}{l}\text { Current working } \\
\text { conditions }\end{array}$ & $\begin{array}{l}\text { What are the workers doing and what are their } \\
\text { conditions. What makes them motivated as } \\
\text { well as demotivating in their current work } \\
\text { conditions }\end{array}$ & Question: Q06 \\
\hline
\end{tabular}

In main study data collection approach will be semi-structured interview have the question lists that will be arranged based on topics: introducing, company overview, social relation at work, job 
characteristic, job guarantee, current working conditions (Denyro Kohar, Amelina and Andi, 2013) those engaged employee informants. The nature of the questions and the ensuing discussion mean that data will be recorded by Google Meet Recording on the conversation or note taking. Moreover, the most dominant variable found later will be the study's focus in developing strategy of employee demotivation and employee motivation to enhance the employee performance. In table 1, an overview of orientation variables, with its concept and question instrument measurement are presented, the arrangement is based on the previous literature review on Denyro Kohar, Amelina and Andi (2013) about indicator employee demotivation and employee motivation.

\section{Population Sample}

There will be one type of informant in this research, the population will be engaged employees who work in Farven Company.

\section{Sampling Techniques}

Sampling technique shows how this study took samples. The employee will be chosen through non probability sampling which is purposive sampling or specifically use judgment sampling. The interview will mainly explore the dimensions of employee motivation and employee demotivation according to the participant experience as the Farven's employee. There will be 3 informants for this research.

Purposive sampling method will be also used in this following phase of data collection to collect the informant. Purposive sampling represents a group of different non-probability sampling techniques. Also known as judgmental, selective or subjective sampling, purposive sampling relies on the judgment of the researcher when it comes to selecting the units (Genio, 2016).

Researcher considered to frequently use this method since the main goal of purposive sampling was to focus on particular characteristics of a population of interest, which will best enable researcher to answer the research questions. The sample being studied is not representative of the population, but for researchers pursuing qualitative research designs, this is not considered to be a weakness.

\section{Analysis Procedure}

Integrating elements from all the above approaches, the study use thematic coding to analyse the qualitative data. The interview results among employees as the primary source in this research will be coded in some specific nodes. The researcher will coding data in order to be able to see all that coded material together, to interpret its variety and to explore its context (Genio, 2016). The probable nodes will be employee demotivation and employee motivation dimensions.

\section{Result}

The qualitative data research in semi-structured interview has been conducted among Farven's employees who have the result of fact finding about the dimensions of employee demotivation and employee motivation.

Table 2: Demotivation Dimensions

\section{Demotivation}

Social Relation at Work

Miscommunication

$16.67 \%$

Argument/ Difference of Opinion $16.67 \%$

Less Cooperation

$11.11 \%$ 


\section{Job Characteristics}

Job Guarantee

$\begin{array}{ll}\text { Lazy to do } & 16.67 \% \\ \text { KPIs have never been met } & 11.11 \% \\ \text { Work is piling up } & 11.11 \% \\ & 33.33 \% \\ \text { Punishment } & 33.33 \% \\ \text { No Income, to cover cost RnD } & 16.67 \% \\ \text { Just for college assignments } & \\ & 21.05 \% \\ \text { Overwhelmed } & 15.79 \% \\ \text { Covid Transition } & 10.53 \% \\ \text { Sales don't increase } & \end{array}$

From the table above, it shows that each indicator has three dimensions that are the most influential in employee demotivation, the percentage is based on the most frequent word mentioned by Farven's Employees. In Social relation at work indicator, Miscommunication and Argument/ Difference of Opinion has the highest percentage with 16.67\%. In Job Characteristic indicator, Lazy to do has the highest percentage with $16.67 \%$. In Job Guarantee indicator, Punishment and No Income, to cover cost $\mathrm{RnD}$ has the highest percentage with 33.33\%. In Current Working Condition indicator, Overwhelmed has the highest percentage with $21.05 \%$.

Table 3: Indicator Percentage of Demotivation

\begin{tabular}{lccc}
\hline Indicator & Total Codes & & Percentage (\%) \\
\hline Social Relation at Work & & 18 & $29.51 \%$ \\
Job Characteristic & 18 & $29.51 \%$ \\
Job Guarantee & 6 & $9.84 \%$ \\
Current Working Condition & 19 & $31.15 \%$ \\
& & & $100.00 \%$ \\
\hline
\end{tabular}

From the table above, it shows that of the four indicators, Current Working Condition is the most influential in employee demotivation with a total of 19 nodes and the percentage is $31.15 \%$.

Table 4: Motivation Dimensions

\begin{tabular}{llc}
\hline Motivation & & \\
\hline \multirow{3}{*}{ Social Relation at Work } & Deeptalk & $12.50 \%$ \\
& Build good relation & $8.33 \%$ \\
& Do together & $8.33 \%$ \\
Job Characteristics & Clear instruction and SOP & $11.11 \%$ \\
& Get a new knowledge & $11.11 \%$ \\
& Solve the problem & $11.11 \%$ \\
Job Guarantee & Reward point & $16.67 \%$ \\
& Income according job desk & $16.67 \%$ \\
& Equally/Fair & $16.67 \%$ \\
Current Working Condition & New working system & $20 \%$ \\
& Support and remind each other & $10 \%$ \\
& Evaluation and Feedback & $10 \%$ \\
\hline
\end{tabular}


From the table above, it shows that each indicator has three dimensions that are the most influential in employee motivation, the percentage is based on the most frequent word mentioned by Farven's Employees. In Social relation at work indicator, Deep Talk has the highest percentage with $12.50 \%$. In Job Characteristic indicator, Clear instruction and SOP and get a new knowledge has the highest percentage with $11.11 \%$. In Job Guarantee indicator, Reward Point and Income according job desk has the highest percentage with $16.67 \%$. In Current Working Condition indicator, New working system has the highest percentage with $20 \%$.

Table 5: Indicator Percentage of Motivation

\begin{tabular}{lccc}
\hline Indicator & Total Codes & & Percentage (\%) \\
\hline Social Relation at Work & & 24 & $41.38 \%$ \\
Job Characteristic & 18 & $31.03 \%$ \\
Job Guarantee & 6 & $10.34 \%$ \\
Current Working Condition & & 10 & $17.24 \%$ \\
& & & $100.00 \%$ \\
\hline
\end{tabular}

From the table above, it shows that of the four indicators, Social Relation at Work is the most influential in employee motivation with a total of 24 nodes and the percentage is $41.38 \%$.

\section{Discussion}

Based on the analysis, the highest indicator is in the current working condition and the three biggest dimensions that affect it are being overwhelmed, covid transition, sales don't increase are variables that play the biggest demotivating role for a Farven startup. It can be concluded that the three dimensions are interrelated, the current condition of the covid pandemic makes employees feel overwhelmed and in the end sales don't increase, this has a significant effect on employee performance.

When the pandemic ends is something that humans cannot control. Being overwhelmed by employees has a significant influence on employee performance, therefore the workload must be in accordance with the abilities and skills of employees so as not to feel overwhelmed. Sales don't increase during the pandemic, it really represents the working condition of Farven. Therefore, perhaps Farven needs to rethink how the job desk of each employee has been divided so far, the amount of responsibility borne by each team member, and also Farven must be able to survive in the covid situation to increase sales. On the motivation factor, the highest indicator is social relations at work and the three largest dimensions that have an effect on employee motivation are deeptalk, build good relations, do together. In its implementation with Farven, this startup might consider more about communication and building relationships between employees.

\section{Conclusion}

The research has conducted the research 3 respondents through semi-structured interview and analyse it with thematic coding. In this study, the research will answer the dimensions of employee demotivation and employee motivation that affect employee performance and the most influential indicator on the dimensions of employee demotivation and employee motivation. From the research findings, the researcher can answer the research question.

i. There are 12 dimensions of Employee Demotivation that affect employee performance which are divided into 4 indicators:

- Indicators of Social Relations in the Workplace: Miscommunication, Arguments / Differences of Opinion, Lack of Cooperation. 
- Job Characteristics Indicators: Lazy to work, KPIs are never met, Work piles up.

- Job Guarantee Indicator: Punishment, No Income, to cover RnD costs, Only for college assignments.

- Current Working Condition Indicators: Overwhelmed, Covid Transition, Sales Not Increasing.

ii. There are 12 dimensions of Employee Motivation that affect employee performance which are divided into 4 indicators:

- Indicators of Social Relations at Work: Deeptalk, Building good relationships, Doing together.

- Job Characteristics Indicators: Clear instructions and SOPs, Gaining new knowledge, Solving Problems.

- Job Guarantee indicators: Reward points, Income according to job desk, Equally.

- Indicators of Current Working Conditions: New Work System, Support and Remind Others, Evaluation and Feedback.

iii. The most influential indicator on the dimension of employee demotivation is Current Working Conditions.

iv. The most influential indicator on the dimensions of employee work motivation is Social Relations at Work.

\section{References}

Asstprof (2013) Employee Development And Its Affect On Their Performance Mrs Archana Agrawal. International Journal of Marketing, Financial Services \& Management Research. Available at: www.indianresearchjournals.com.

Denyro Kohar, W., Amelina, S. \& Andi, D. (2013). Model Pengukuran Tingkat Motivasi Dan Demotivasi Pekerja Proyek Konstruksi Di Surabaya.

Falout, J., Elwood, J. \& Hood, M. (2009a). Demotivation: Affective states and learning outcomes. System, 37(3), pp. 403-417. doi: 10.1016/j.system.2009.03.004.

Fulmer, I. S. \& Ployhart, R. E. (2014). Our Most Important Asset': A Multidisciplinary/Multilevel Review of Human Capital Valuation for Research and Practice. Journal of Management, 40(1), pp. 161-192. doi: 10.1177/0149206313511271.

Genio, K. (2016). An Analysis Of Recruitment And Job Training Method Effectiveness To Employee Engagement In Bandung Culinary Start-Up. Final Project Bachelor of Entrepreneurship Program School of Business and Management Institut Teknologi Bandung. Available at: www.acaciahrsolutions.com,.

Halushchak, O. \& Halushchak, M. (2016). The causes of appearance and ways of staff s demotivation solving in organizations. Socio-Economic Problems and the State, 14(1), 138-144. doi: 10.14254/2223-3822.2016.14-1.16.

Inuwa, M. (2016). Job Satisfaction and Employee Performance: An Empirical Approach. The Millennium University Journal, 1(1).

Jarour (2014) Person Demotivation in Organizational Life. Available at: www.ijbssnet.com.

Kamal, M. \& Ii, H. (2012) Factors Affecting Employee's Motivation In The Fast Food Industry: The Case Of Kfc Uk Ltd. Available at: www.researchjournals.co.uk.

Liedianto, W. and Andi, D. (no date) Pengukuran Tingkat Motivasi Dan Demotivasi Pekerja Konstruksi Pada Suatu Proyek Di Surabaya.

Mayasari, L. (2020) The Influence Of Employee Demotivation And Employee Motivation On Employee Performance: A Study Of Veesit Technology Final Project.

Sohail, A., Safdar, R., Saleem, S., Ansar GJ, S. and Azeem, M. (2014) Effect of Work Motivation and Organizational Commitment on Job Satisfaction: (A Case of Education Industry in Pakistan). 